\title{
Stability Analysis of Micro-grid with Multiple Convertors
}

\author{
Tianyi MA* \\ Beijing Institute of Graphic Communication \\ School of mechanical and electrical engineering \\ Beijing, China \\ E-mail: matianyi@bigc.edu.cn \\ $+{ }^{*}$ Corresponding author \\ Mingming ZHANG \\ Beijing Institute of Graphic Communication \\ School of mechanical and electrical engineering \\ Beijing, China \\ E-mail: zhangmm@bigc.edu.cn
}

\author{
Jinyao LI \\ Beijing Institute of Graphic Communication \\ School of mechanical and electrical engineering \\ Beijing, China \\ E-mail: jinyaoli@bigc.edu.cn
}

\section{Shaoru MA}

Beijing Institute of Graphic Communication

School of mechanical and electrical engineering

Beijing, China

E-mail: $18713516901 @ 163 . c o m$

\begin{abstract}
Most of the Distributed Generators (DG) in microgrid are interfaced with convertors. Under the islanding mode, the frequency and voltage of micro-grid are supported by convertors. These convertors are called Voltage Source Convertors (VSC). The convertors, only supplying power for micro-grid, are called Current Source Converters (CSC). Under islanding mode, the performance of VSCs will affect micro-grid frequency stability and voltage stability. This paper presents a 3-Bus micro-grid system to analyze the stability of micro-grid under islanding mode. Based on this micro-grid, 12 cases of simulation study are carried out. To judge which parameters affect the stability of micro-grid in islanding mode, the control parameter of VSC, the transmission line parameter of micro-grid are considered in these cases.
\end{abstract}

Keywords-micro-grid; stability; islanding mode; VSC; VSC control parameter

\section{INTRODUCTION}

In order to reduce the adverse effect and make the full use of DG, micro-grid is presented ${ }^{[1-3]}$. The micro-grid, treated as a controllable cell in the main grid, is constituted by DGs and loads. It can fulfill the requests of distributed network in a few seconds ${ }^{[4]}$, improve the power reliability, reduce the loss of feeder, and maintain local voltage stability. Micro-grid has four operating modes, grid connected mode, islanding mode, grid connected to islanding mode, and islanding to grid connected mode. Normally, the micro-grid is operated under grid connected mode. When faults occur in main grid, the micro-grid will disconnect from the main grid and work under islanding mode.

As islanding mode is the most important character of a micro-grid, more and more researchers pay attention to how to keep reliable operation of this mode. Paper [5] proposes a kind of micro-grid, in which all DC sides of the convertors are connected together. This method can make the microgrid ac control easier. Paper [6] designs an ac bus micro-grid. The convertors are controlled by master/slave method. The master DG convertor is controlled to maintain the voltage and frequency, and the others operated following the master DG convertor. Paper [7] also uses the ac bus topology but all the convertors are VSCs. Because the VSC method can make micro-grid more flexible and reliable, it is widely used. When the micro-grid works under islanding mode, all the VSCs maintain the micro-grid frequency and voltage together, the VSC performance will also have an effect on the operation of micro-grid islanding mode. A 3-Bus microgrid is introduced in this paper. The second part introduces the control model of VSC, and proposes the parameters affect VSC frequency and voltage control. The third part carries out 12 cases about the parameters. The last part gives the conclusion according to the simulation results.

\section{THE MICRO-GRID TOPOLOGY}

A micro-grid formed by convertors is shown in Fig.1. In this figure, $\mathrm{CB}$ represents the circuit breaker, L represents the static load of micro-grid, and TL represents the transmission line of micro-grid.

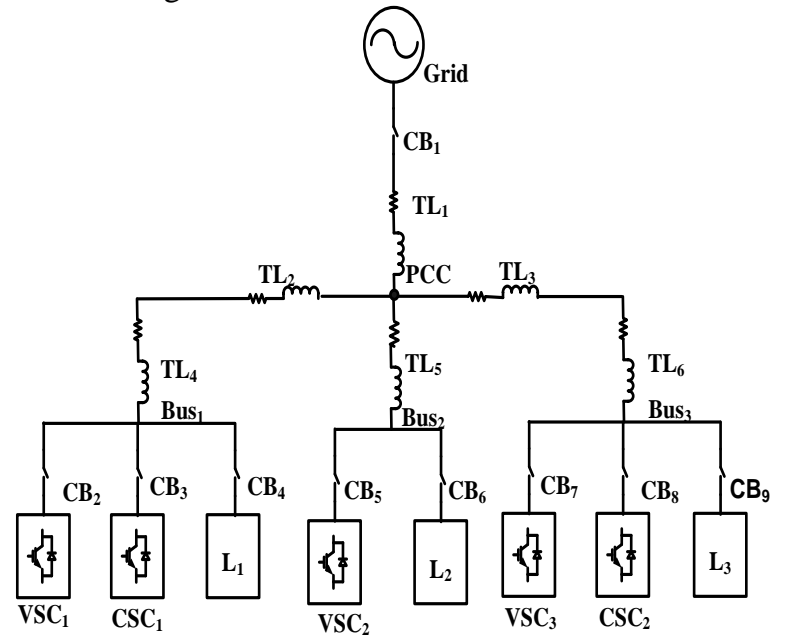

Figure 1. Topology of micro-grid 


\section{PARAMETERS AFFECT VSC FREQUENCY AND VOLTAGE CONTROL}

The VSC control method is carried out according to Fig.2.In Fig.2, VS represents the voltage sensor, and CS represents the current sensor. The frequency and voltage control block is shown in Fig.3.

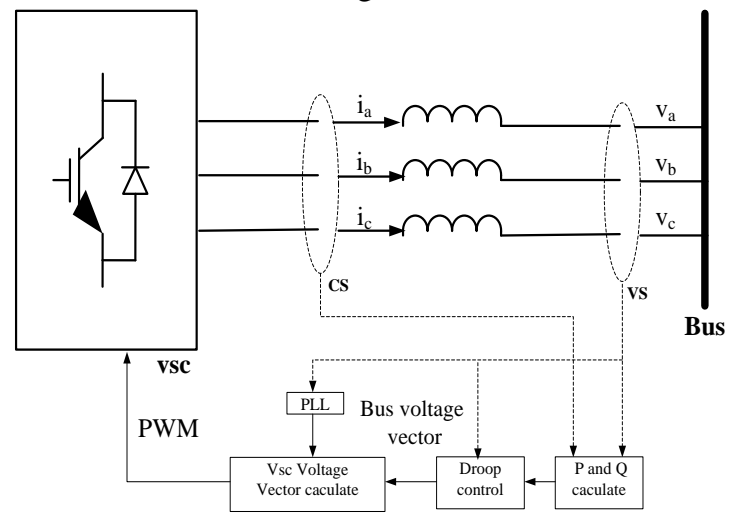

Figure 2. Structure of vsc controller.

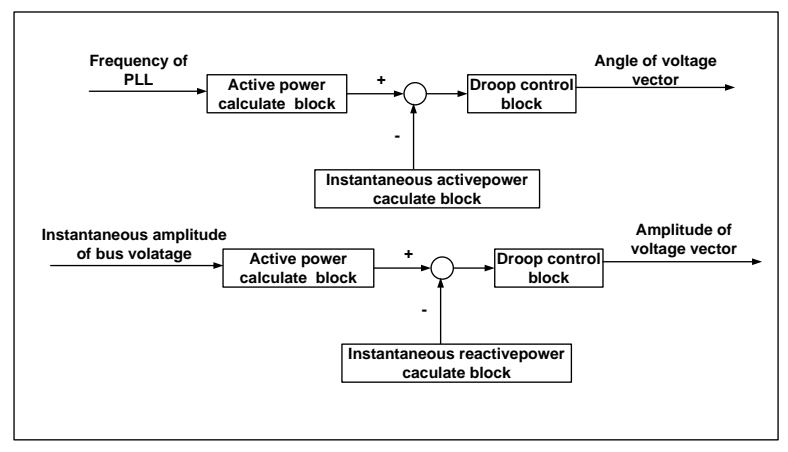

Figure 3. VSC frequency and voltage control structure

According to Fig.3 we can obtain the transfer function of VSC shown in equation 1.

$$
\left\{\begin{array}{c}
\omega^{*}=\omega_{0}+k_{p}\left(P_{0}-P_{v} \frac{\omega_{c}}{s+\omega_{c}}\right) \\
E^{*}=E_{0}+\left(k_{p}+\frac{k_{i}}{s}\right)\left(Q_{0}-Q_{v} \frac{\omega_{c}}{s+\omega_{c}}\right)
\end{array}\right.
$$

In equation $1, \omega_{0}$ represents the frequency measured by PLL, $\omega_{c}$ represents the LPF parameter of power measurement, and $\mathrm{E}_{0}$ represents the voltage of VSC coupling point.

The transfer function shows that the variation of $\omega_{0}$ will affect the frequency control of VSC. The variation of $E_{0}$ will affect the voltage control. The variation of $\omega_{c}$ will affect both frequency and voltage control. The three parameters are influenced by PLL response parameter, the length of transmission line, and the LPF parameter.

\section{ANALYSIS BASED ON SIMULATION}

In order to research the three parameters affect microgrid islanding mode. 12 cases are carried out. Each parameter includes 4 cases. In order to estimate the influence, an ideal condition is used as standard. The simulating parameters are listed in Table I to Table III. All the cases are carried out under the micro-grid islanding mode. The static load will change $0.5 \mathrm{p} . \mathrm{u}$. at the time of $0.5 \mathrm{~s}$.

TABLE I. Simulating Parameter of CASe1 to CASE4

The effect of pll response parameter on micro-grid islanding mode

\begin{tabular}{|c|c|c|c|}
\hline Case1 & Case2 & Case3 & Case4 \\
\hline $\begin{array}{l}\omega_{01}=5000 \mathrm{rad} / \mathrm{s} \\
\omega_{02}=5000 \mathrm{rad} / \mathrm{s} \\
\omega_{03}=5000 \mathrm{rad} / \mathrm{s}\end{array}$ & $\begin{array}{l}\omega_{01}=5000 \mathrm{rad} / \mathrm{s} \\
\omega_{02}=5000 \mathrm{rad} / \mathrm{s} \\
\omega_{03}=5000 \mathrm{rad} / \mathrm{s}\end{array}$ & $\begin{array}{l}\omega_{01}=5000 \mathrm{rad} / \mathrm{s} \\
\omega_{02}=5000 \mathrm{rad} / \mathrm{s} \\
\omega_{03}=5000 \mathrm{rad} / \mathrm{s}\end{array}$ & $\begin{array}{l}\omega_{01}=5000 \mathrm{rad} / \mathrm{s} \\
\omega_{02}=5000 \mathrm{rad} / \mathrm{s} \\
\omega_{03}=5000 \mathrm{rad} / \mathrm{s}\end{array}$ \\
\hline $\begin{array}{l}\mathrm{Kp}_{\mathrm{p} 111}=120 \\
\mathrm{Kp}_{\mathrm{pll}}=120 \\
\mathrm{Kp}_{\mathrm{pll}}=120, \\
\mathrm{Ki}_{\mathrm{pl11}}=2800 \\
\mathrm{Ki}_{\text {pl12 }}=2800 \\
\mathrm{Ki}_{\text {pl13 }}=2800\end{array}$ & $\begin{array}{l}\mathrm{Kp}_{\mathrm{pll1}}=120 \\
\mathrm{Kp}_{\mathrm{pl1} 2}=24 \\
\mathrm{Kp}_{\mathrm{p} 113}=9.6 \\
\mathrm{Ki}_{\mathrm{p} 111}=2800 \\
\mathrm{Ki}_{\mathrm{p} 112}=560 \\
\mathrm{Ki}_{\mathrm{pl13}}=224\end{array}$ & $\begin{array}{l}\mathrm{Kp}_{\mathrm{pll1}}=120 \\
\mathrm{Kp}_{\mathrm{pll} 2}=60 \\
\mathrm{Kp}_{\mathrm{pll} 3}=3 \\
\mathrm{Ki}_{\mathrm{p} 111}=2800 \\
\mathrm{Ki}_{\mathrm{pll}}=1400 \\
\mathrm{Ki}_{\mathrm{pll3}}=70\end{array}$ & $\begin{array}{l}\mathrm{Kp}_{\mathrm{pll1}}=120 \\
\mathrm{Kp}_{\mathrm{pll} 2}=24 \\
\mathrm{Kp}_{\mathrm{pll} 3}=9.6 \\
\mathrm{Ki}_{\mathrm{p} 111}=2800 \\
\mathrm{Ki}_{\mathrm{p} 112}=560 \\
\mathrm{Ki}_{\mathrm{p} 113}=224\end{array}$ \\
\hline $\begin{array}{l}\mathrm{TL}_{2}=0.06 \mathrm{~km} \\
\mathrm{TL}_{2}=0.09 \mathrm{~km} \\
\mathrm{TL}_{2}=0.05 \mathrm{~km} \\
\mathrm{TL}_{2}=0.03 \mathrm{~km} \\
\mathrm{TL}_{2}=0.05 \mathrm{~km}\end{array}$ & $\begin{array}{l}\mathrm{TL}_{2}=0.6 \mathrm{~km} \\
\mathrm{TL}_{2}=0.9 \mathrm{~km} \\
\mathrm{TL}_{2}=0.5 \mathrm{~km} \\
\mathrm{TL}_{2}=0.3 \mathrm{~km} \\
\mathrm{TL}_{2}=0.5 \mathrm{~km}\end{array}$ & $\begin{array}{c}\mathrm{TL}_{2}=1.2 \mathrm{~km} \\
\mathrm{TL}_{2}=1.8 \mathrm{~km} \\
\mathrm{TL}_{2}=1 \mathrm{~km} \\
\mathrm{TL}_{2}=0.6 \mathrm{~km} \\
\mathrm{TL}_{2}=1 \mathrm{~km}\end{array}$ & $\begin{array}{l}\mathrm{TL}_{2}=6 \mathrm{~km} \\
\mathrm{TL}_{2}=9 \mathrm{~km} \\
\mathrm{TL}_{2}=5 \mathrm{~km} \\
\mathrm{TL}_{2}=3 \mathrm{~km} \\
\mathrm{TL}_{2}=5 \mathrm{~km}\end{array}$ \\
\hline
\end{tabular}

TABLE II. Simulating Parameter of CASE5 To CASE8

The effect of transmission line length on micro-grid islanding mode

\begin{tabular}{|c|c|c|c|}
\hline Case 5 & Case6 & Case 7 & Case8 \\
\hline $\begin{array}{l}\omega_{01}=5000 \mathrm{rad} / \mathrm{s} \\
\omega_{02}=5000 \mathrm{rad} / \mathrm{s} \\
\omega_{03}=5000 \mathrm{rad} / \mathrm{s}\end{array}$ & $\begin{array}{l}\omega_{01}=5000 \mathrm{rad} / \mathrm{s} \\
\omega_{02}=5000 \mathrm{rad} / \mathrm{s} \\
\omega_{03}=5000 \mathrm{rad} / \mathrm{s}\end{array}$ & $\begin{array}{l}\omega_{01}=5000 \mathrm{rad} / \mathrm{s} \\
\omega_{02}=5000 \mathrm{rad} / \mathrm{s} \\
\omega_{03}=5000 \mathrm{rad} / \mathrm{s}\end{array}$ & $\begin{array}{l}\omega_{01}=5000 \mathrm{rad} / \mathrm{s} \\
\omega_{02}=5000 \mathrm{rad} / \mathrm{s} \\
\omega_{03}=5000 \mathrm{rad} / \mathrm{s}\end{array}$ \\
\hline $\begin{array}{l}\mathrm{Kp}_{\mathrm{p} 111}=120 \\
\mathrm{Kp}_{\mathrm{pll}}=120 \\
\mathrm{Kp}_{\mathrm{pll}}=120 \\
\mathrm{Ki}_{\mathrm{p} I 11}=2800 \\
\mathrm{Ki}_{\mathrm{pll}}=2800 \\
\mathrm{Ki}_{\mathrm{p} 113}=2800\end{array}$ & $\begin{array}{l}\mathrm{Kp}_{\mathrm{pll1}}=120 \\
\mathrm{Kp}_{\mathrm{pll}}=120 \\
\mathrm{Kp}_{\mathrm{pll}}=120, \\
\mathrm{Ki}_{\mathrm{p} 111}=2800 \\
\mathrm{Ki}_{\mathrm{pll2}}=2800 \\
\mathrm{Ki}_{\mathrm{pll3}}=2800\end{array}$ & $\begin{array}{l}\mathrm{Kp}_{\mathrm{pll1}}=120 \\
\mathrm{Kp}_{\mathrm{pl1}}=120 \\
\mathrm{Kp}_{\mathrm{pl13}}=120, \\
\mathrm{Ki}_{\mathrm{p} 111}=2800 \\
\mathrm{Ki}_{\mathrm{pl12}}=2800 \\
\mathrm{Ki}_{\mathrm{p} 113}=2800\end{array}$ & $\begin{array}{l}\mathrm{Kp}_{\mathrm{p} 111}=120 \\
\mathrm{Kp}_{\mathrm{pl12}}=120 \\
\mathrm{Kp}_{\mathrm{pl13}}=120 \\
\mathrm{Ki}_{\mathrm{pl11}}=2800 \\
\mathrm{Ki}_{\mathrm{pl12}}=2800 \\
\mathrm{Ki}_{\mathrm{p} 113}=2800\end{array}$ \\
\hline $\begin{array}{l}\mathrm{TL}_{2}=0.06 \mathrm{~km} \\
\mathrm{TL}_{2}=0.09 \mathrm{~km} \\
\mathrm{TL}_{2}=0.05 \mathrm{~km} \\
\mathrm{TL}_{2}=0.03 \mathrm{~km} \\
\mathrm{TL}_{2}=0.05 \mathrm{~km}\end{array}$ & $\begin{array}{l}\mathrm{TL}_{2}=0.6 \mathrm{~km} \\
\mathrm{TL}_{2}=0.9 \mathrm{~km} \\
\mathrm{TL}_{2}=0.5 \mathrm{~km} \\
\mathrm{TL}_{2}=0.3 \mathrm{~km} \\
\mathrm{TL}_{2}=0.5 \mathrm{~km}\end{array}$ & $\begin{aligned} \mathrm{TL}_{2} & =1.2 \mathrm{~km} \\
\mathrm{TL}_{2} & =1.8 \mathrm{~km} \\
\mathrm{TL}_{2} & =1 \mathrm{~km} \\
\mathrm{TL}_{2} & =0.6 \mathrm{~km} \\
\mathrm{TL}_{2} & =1 \mathrm{~km}\end{aligned}$ & $\begin{array}{l}\mathrm{TL}_{2}=6 \mathrm{~km} \\
\mathrm{TL}_{2}=9 \mathrm{~km} \\
\mathrm{TL}_{2}=5 \mathrm{~km} \\
\mathrm{TL}_{2}=3 \mathrm{~km} \\
\mathrm{TL}_{2}=5 \mathrm{~km}\end{array}$ \\
\hline
\end{tabular}


TABle III. Simulating Parameter of CASe9 To CASE12

\begin{tabular}{|c|c|c|c|}
\hline Case9 & Case10 & Case11 & Case12 \\
\hline $\begin{array}{l}\omega_{01}=5000 \mathrm{rad} / \mathrm{s} \\
\omega_{02}=5000 \mathrm{rad} / \mathrm{s} \\
\omega_{03}=5000 \mathrm{rad} / \mathrm{s}\end{array}$ & $\begin{array}{l}\omega_{01}=5000 \mathrm{rad} / \mathrm{s} \\
\omega_{02}=500 \mathrm{rad} / \mathrm{s} \\
\omega_{03}=200 \mathrm{rad} / \mathrm{s}\end{array}$ & $\begin{array}{l}\omega_{01}=5000 \mathrm{rad} / \mathrm{s} \\
\omega_{02}=200 \mathrm{rad} / \mathrm{s} \\
\omega_{03}=20 \mathrm{rad} / \mathrm{s}\end{array}$ & $\begin{array}{l}\omega_{01}=5000 \mathrm{rad} / \mathrm{s} \\
\omega_{02}=200 \mathrm{rad} / \mathrm{s} \\
\omega_{03}=100 \mathrm{rad} / \mathrm{s}\end{array}$ \\
\hline $\begin{array}{l}\mathrm{Kp}_{\mathrm{p} 111}=120 \\
\mathrm{Kp}_{\mathrm{p} 112}=120 \\
\mathrm{Kp}_{\mathrm{p} 113}=120 \\
\mathrm{Ki}_{\text {pl11 }}=2800 \\
\mathrm{Ki}_{\mathrm{pl12}}=2800 \\
\mathrm{Ki}_{\mathrm{p} 113}=2800\end{array}$ & $\begin{array}{l}\mathrm{Kp}_{\mathrm{p} \| 11}=120 \\
\mathrm{Kp}_{\mathrm{p} 112}=120 \\
\mathrm{Kp}_{\mathrm{p} 113}=120 \\
\mathrm{Ki}_{\text {pl11 }}=2800 \\
\mathrm{Ki}_{\mathrm{p} 112}=2800 \\
\mathrm{Ki}_{\mathrm{p} 113}=2800\end{array}$ & $\begin{array}{l}\mathrm{Kp}_{\mathrm{p} 111}=120 \\
\mathrm{Kp}_{\mathrm{p} 112}=120 \\
\mathrm{Kp}_{\mathrm{pl13}}=120, \\
\mathrm{Ki}_{\text {p111 }}=2800 \\
\mathrm{Ki}_{\mathrm{p} 112}=2800 \\
\mathrm{Ki}_{\mathrm{p} 113}=2800\end{array}$ & $\begin{array}{l}\mathrm{Kp}_{\mathrm{p} \| 11}=120 \\
\mathrm{Kp}_{\mathrm{p} 112}=120 \\
\mathrm{Kp}_{\mathrm{p} 113}=120 \\
\mathrm{Ki}_{\mathrm{pl11}}=2800 \\
\mathrm{Ki}_{\mathrm{p} 112}=2800 \\
\mathrm{Ki}_{\mathrm{pl13}}=2800\end{array}$ \\
\hline $\begin{array}{l}\mathrm{TL}_{2}=0.06 \mathrm{~km} \\
\mathrm{TL}_{2}=0.09 \mathrm{~km} \\
\mathrm{TL}_{2}=0.05 \mathrm{~km} \\
\mathrm{TL}_{2}=0.03 \mathrm{~km} \\
\mathrm{TL}_{2}=0.05 \mathrm{~km}\end{array}$ & $\begin{array}{l}\mathrm{TL}_{2}=0.06 \mathrm{~km} \\
\mathrm{TL}_{2}=0.09 \mathrm{~km} \\
\mathrm{TL}_{2}=0.05 \mathrm{~km} \\
\mathrm{TL}_{2}=0.03 \mathrm{~km} \\
\mathrm{TL}_{2}=0.05 \mathrm{~km}\end{array}$ & $\begin{array}{l}\mathrm{TL}_{2}=0.06 \mathrm{~km} \\
\mathrm{TL}_{2}=0.09 \mathrm{~km} \\
\mathrm{TL}_{2}=0.05 \mathrm{~km} \\
\mathrm{TL}_{2}=0.03 \mathrm{~km} \\
\mathrm{TL}_{2}=0.05 \mathrm{~km}\end{array}$ & $\begin{array}{l}\mathrm{TL}_{2}=0.06 \mathrm{~km} \\
\mathrm{TL}_{2}=0.09 \mathrm{~km} \\
\mathrm{TL}_{2}=0.05 \mathrm{~km} \\
\mathrm{TL}_{2}=0.03 \mathrm{~km} \\
\mathrm{TL}_{2}=0.05 \mathrm{~km}\end{array}$ \\
\hline
\end{tabular}

\section{A. Analysis Based on Casel to Case4}

The simulating results of case 1 to case 4 are shown in Fig.4.

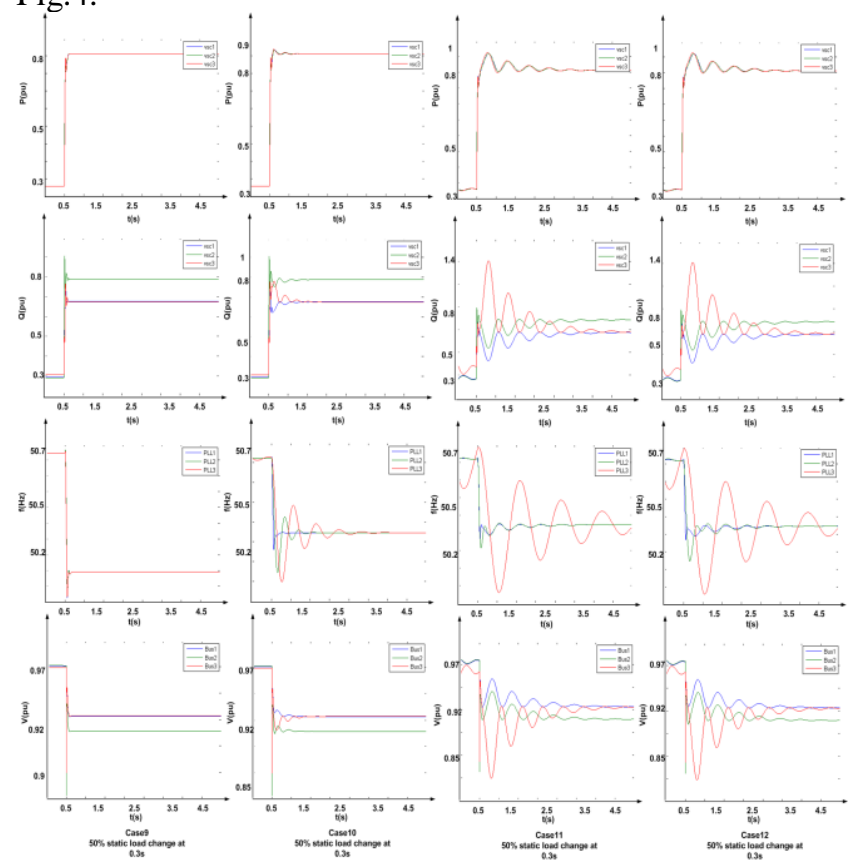

Figure 4. Simulating result of case 1 to case 4

In order to estimate the influence of this parameter, the simulation results are concluded by three parts, which is shown in Table IV. Part1 is the active power over shoot of a VSC, the unit is p.u. value. Part2 is the response time of a VSC, the unit is second. Part3 is the response time of the system, the unit is second.
TABLE IV. TABLE TyPe STYLES

The effect of pll response parameter on micro-grid islanding mode

\begin{tabular}{|c|c|c|c|c|c|c|}
\hline & \multicolumn{3}{|c|}{ Case1 } & \multicolumn{3}{|c|}{ Case2 } \\
\hline & $\mathrm{VSC}_{1}$ & $\mathrm{VSC}_{2}$ & $\mathrm{VSC}_{1}$ & $\mathrm{VSC}_{2}$ & $\mathrm{VSC}_{1}$ & $\mathrm{VSC}_{2}$ \\
\hline Part1 & 0 & 0 & 0 & 0 & 0 & 0 \\
\hline Part2 & 0.05 & 0.05 & 0.05 & 0.05 & 0.05 & 0.05 \\
\hline \multirow[t]{3}{*}{ Part3 } & \multicolumn{3}{|c|}{0.05} & \multicolumn{3}{|c|}{1.1} \\
\hline & \multicolumn{3}{|c|}{ Case3 } & \multicolumn{3}{|c|}{ Case4 } \\
\hline & $\mathrm{VSC}_{1}$ & $\mathrm{VSC}_{2}$ & $\mathrm{VSC}_{1}$ & $\mathrm{VSC}_{2}$ & $\mathrm{VSC}_{1}$ & $\mathrm{VSC}_{2}$ \\
\hline Part1 & 0.2 & 0.2 & 0.2 & 0.2 & 0.2 & 0.2 \\
\hline Part2 & 2 & 2.2 & 2 & 2.2 & 2 & 2.2 \\
\hline Part3 & \multicolumn{3}{|c|}{3.5} & \multicolumn{3}{|c|}{3.5} \\
\hline
\end{tabular}

From Table IV, we can see, the VSC with slowest pll response parameter cause the greatest influence on system. The VSC pll response parameter slower, cause the larger active power over shoot and longer response time on the system.

\section{B. Analysis Based on Case5 to Case8}

The simulation results of case 5 to case 8 are shown in Fig.5.

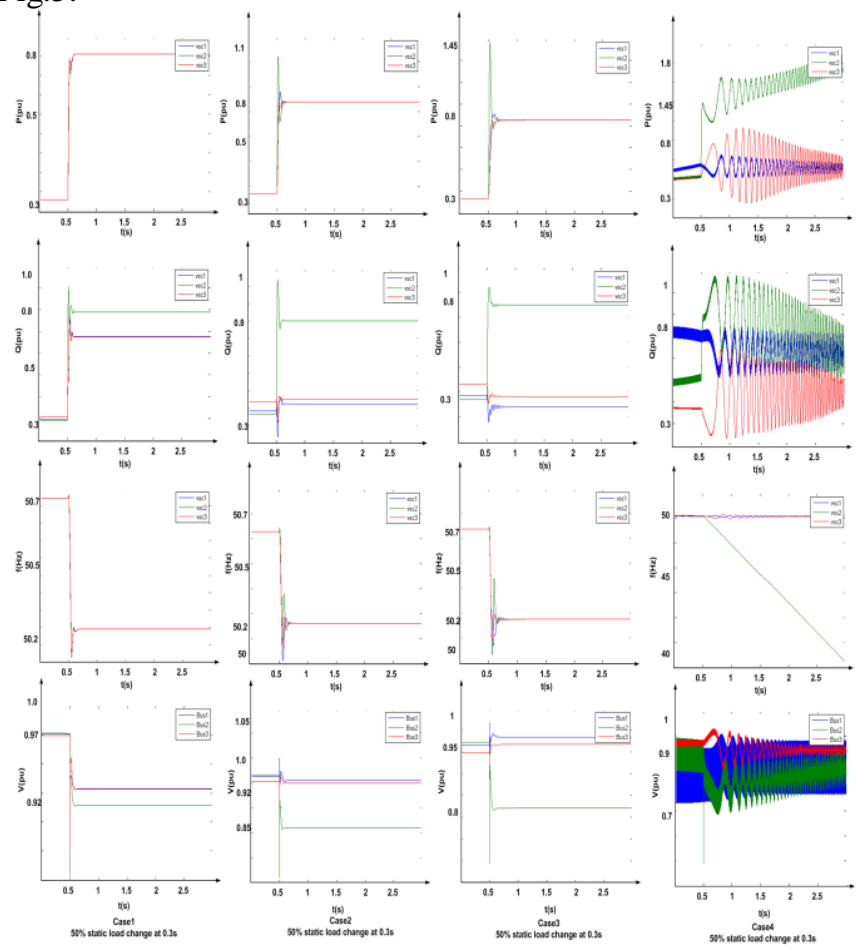

Figure 5. Simulating result of case5 to case8 
In order to estimate the influence of this parameter, the simulation results are concluded by three parts, which is shown in Table V. Part1 is the active power over shoot of a VSC, the unit is p.u value. Part2 is the ac bus voltage over shoot, the unit is p.u value. Part3 is the system response time, the unit is second.

TABLE V. Simulating Result of CASE5 to CASE8

\begin{tabular}{|c|c|c|c|c|}
\hline \multicolumn{5}{|c|}{ The effect of transmission line length on micro-grid islanding mode } \\
\hline & Case5 & Case6 & Case 7 & Case8 \\
\hline Part1 & 0 & 0.23 & 0.65 & 1 \\
\hline Part2 & 0 & 0.03 & 0.02 & 0.2 \\
\hline Part3 & 0.1 & 0.2 & 0.5 & inf \\
\hline
\end{tabular}

From table V, we can see, the longer transmission line parameter lead to lager active power over shoot and ac bus voltage over shoot. The longer transmission line leads to more system response time. The longer transmission line also leads to worse system stability.

\section{Analysis Based on Case9 to Case12}

The simulation results of case 5 to case9 are shown in Fig.6.

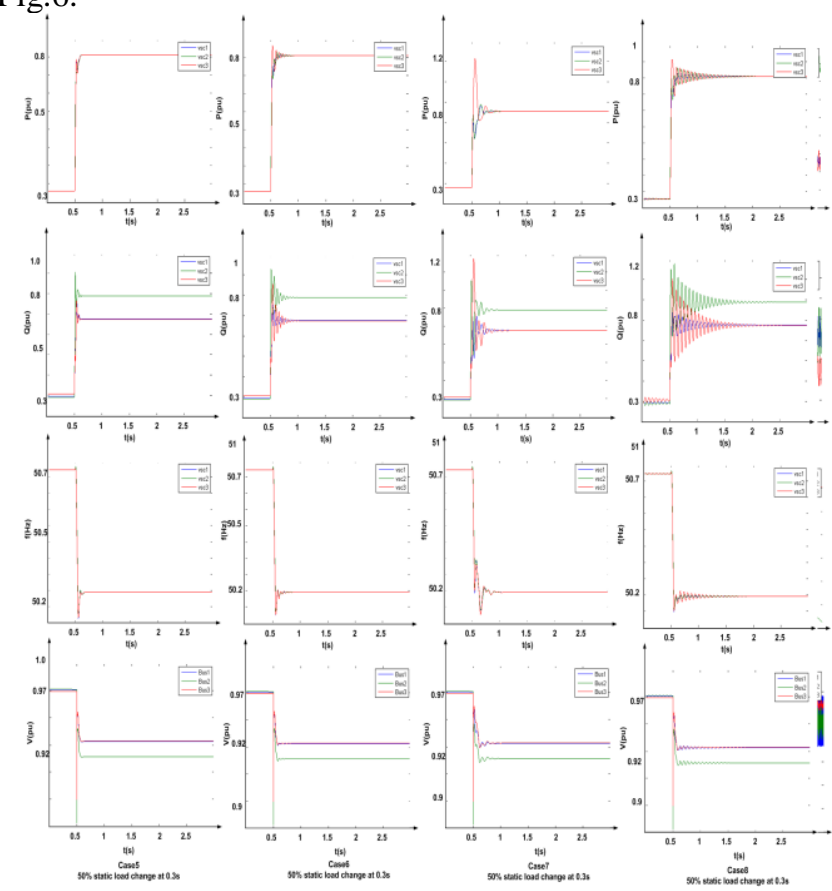

Figure 6. Simulating result of case 9 to case 12

In order to estimate the influence of this parameter, the simulation results are concluded by three parts, which is shown in Table VI. Part1 is the active power over shoot of a VSC, the unit is p.u value. Part2 is the reactive power over shoot, the unit is p.u value. Part3 is the system response time, the unit is second.
TABLE VI. TABLE TyPE STYLES

\begin{tabular}{|c|c|c|c|c|c|c|}
\hline \multicolumn{7}{|c|}{ The effect of LPF parameter on micro-grid islanding mode } \\
\hline & \multicolumn{3}{|c|}{ Case9 } & \multicolumn{3}{|c|}{ Case10 } \\
\hline & VSC1 & $\mathrm{VSC} 2$ & VSC1 & $\mathrm{VSC}_{2}$ & $\mathrm{VSC}_{1}$ & $\mathrm{VSC}_{2}$ \\
\hline Part1 & 0 & 0 & 0 & 0 & 0 & 0 \\
\hline Part2 & 0.1 & 0.1 & 0.1 & 0.05 & 0.05 & 0.05 \\
\hline \multirow[t]{3}{*}{ Part3 } & \multicolumn{3}{|c|}{0.05} & \multicolumn{3}{|c|}{0.4} \\
\hline & \multicolumn{3}{|c|}{ Case11 } & \multicolumn{3}{|c|}{ Case12 } \\
\hline & VSC1 & VSC2 & VSC1 & VSC2 & VSC1 & VSC2 \\
\hline Part1 & 0.05 & 0.06 & 0.05 & 0.06 & 0.05 & 0.06 \\
\hline Part2 & 0.1 & 0.3 & 0.1 & 0.3 & 0.1 & 0.3 \\
\hline Part3 & \multicolumn{3}{|c|}{0.6} & \multicolumn{3}{|c|}{1.5} \\
\hline
\end{tabular}

From Table VI, we can see, the system response time is influenced by LPF parameter. The system active power overshoot and reactive power over shoot are also influenced by transmission line parameter.

\section{CONCLUSIONS}

The micro-grid frequency and voltage are controlled by VSCs under islanding mode. The performance of VSC will affect micro-grid islanding mode operation state. The simulation results indicate that both VSC control parameter and micro-grid transmission line parameter will influence the operation of micro-grid islanding mode, but only the transmission line parameter will have an effect on the stability of micro-grid.

\section{ACKNOWLEDGMENT}

The paper is supported by the Beijing Education Commission R\&D program (Grant No. KM20161005009), and Postdoctoral research activities in Beijing (Grant No. 1000200273).

\section{REFERENCES}

[1] D'adamo C, Abbey C, Jupy S, et al. Development and Operation of Active Distribution Networks: Result of CIGRE C6.11 Working Group.CIGRE'2011. Frankfurt:Paper 0311

[2] Rocabert J, Luna A, Blaabjerg F, et al. Control of Power Converters in AC Microgrids[J]. IEEE Transactions on Power Electronics, 2012,27(11):4734-4749.

[3] Chun-Xia D, Bin L. Multi-Agent Based Hierarchical Hybrid Control for Smart Microgrid[J]. IEEE Transactions on Smart Grid, 2013,4(2):771-778

[4] Wandhare R G, Thale S, Agarwal V. Reconfigurable Hierarchical Control of a Microgrid Developed with PV, Wind, Micro-hydro, Fuel cell and Ultra-capacitor: Applied Power Electronics Conference and Exposition (APEC), 2013 Twenty-Eighth Annual IEEE, Long Beach, CA, 2013[C].2013 x000a_17-21 March 2013. 2799-2806. 
[5] J. Bryan, R. Duke, and S. Round. "Decentralized generator scheduling in a nanogrid using DC bus signalling". IEEE Power Engineering Society Summer Meeting, vol. 2, pp. 977 - 982, June, 2004.

[6] J. M. Guerrero, L. Hang, and J. Uceda. "Control of Distributed Uninterruptible Power Supply Systems," IEEE Trans. Ind. Electron, Special Issue on UPS Systems, vol. 55, pp 2845-2859, 2008
[7] J. C. Vasquez, J. M. Guerrero, E. Gregorio, P. Rodriguez, R. Teodorescu, and F. Blaabjerg. "Adaptive droop control applied to distributed generation inverters connected to the grid," in IEEE International Symposium on Industrial Electronics ISIE'08, pp 24202425,2008 . 